\title{
Morphometry and molecular characterisation of semen in four carp species
}

\author{
N. SHAMNA ${ }^{1,2}$, L. SOMASHEKAR ${ }^{1}$, N. SRIDHAR ${ }^{3}$, S. PARTHIPAN $^{1}$, A. ARANGASAMY ${ }^{1}$, \\ S. DASGUPTA ${ }^{2}$, N. P. SAHU ${ }^{2}$, F. J. FAWOLE ${ }^{2,4}$ AND S. SELVARAJU*1 \\ ${ }^{1}$ ICAR-National Institute of Animal Nutrition and Physiology, Adugodi, Bangalore - 560 030, Karnataka, India \\ ${ }^{2}$ Fish Nutrition, Biochemistry and Physiology Division, ICAR-Central Institute of Fisheries Education, Mumbai - 400061 \\ Maharashtra, India \\ ${ }^{3}$ Regional Research Centre of ICAR-Central Institute of Freshwater Aquaculture, Hesserghatta Lake P. O. \\ Bangalore - 560 089, Karnataka, India \\ ${ }^{4}$ Department of Aquaculture and Fisheries, University of Ilorin, Ilorin, Nigeria \\ e-mail: selvarajuars@gmail.com
}

\begin{abstract}
Present study aimed to compare the morphometric features of sperm and seminal protein profile of four cyprinid species viz. Labeo rohita (Hamilton, 1822), Labeo fimbriatus (Bloch, 1795), Cyprinus carpio (Linnaeus, 1758) and Puntius carnaticus (Jerdon, 1849) in order to elucidate quantitative characteristics of sperm morphology and seminal protein profiles within the family. Morphological studies revealed that carps have uniflagellate, acrosome less sperm with an ovoid head and irregular shaped mid piece. Size of sperm in terms of length and breadth showed significant variation among the four species studied. The sperm and seminal protein profiles of Puntius carnaticus differed from other three groups with the presence of proteins with molecular mass of 15 and $49 \mathrm{kDa}$ and absence of four proteins equivalent to molecular mass of 13, 20, 21 and $23 \mathrm{kDa}$. Two dimensional gel electrophoresis (2D-GE) analysis of sperm protein profile between Puntius carnaticus and Labe orohita revealed presence of 237 protein spots.
\end{abstract}

Keywords: Cyprinid, Morphometry, Protein profiling, SDS-PAGE, Sperm

\section{Introduction}

Fish seed and feed are two major constraints in the growing aquaculture production and it became necessary to find out new techniques and technologies to enhance the breeding and seed production of fish for sustainable aquaculture enterprise (Jacobson et al., 2005; Ayyappan et al., 2011; Pandey, 2013). It has been reported in cattle that breed selection can be done based on the quality of milt and sperm proteins, which supports successful reproduction (Selvaraju et al., 2009). Unlike other terrestrial animals, fish have a range of reproductive patterns (Maricchiolo et al., 2004) and the sperm morphology can be varied due to the various developmental processes during evolution (Bonilla and $\mathrm{Xu}, 2008$ ).

Structure and the molecular composition of sperm vary widely among fish and it is hard to correlate the sperm structure with taxonomy (Mattei, 1991). So far, the studies related to morphological and structural analysis of fish sperm, especially freshwater fish were done from an evolutionary point of view (Baccetti et al., 1984; Mattei, 1991; Maricchiolo et al., 2002). Recent studies shed more light on the variations of sperm even at species level. Sometimes, the general description of sperm structure and organisation of a family may not be sufficient for developing a strategy for successful breeding of fish. Quality of the milt depends on various characteristics of sperm and seminal plasma components (Migaud et al., 2013). So the protein composition of seminal plasma and sperm need to be studied.

Proteomic analysis of sperm cells in animals including fish has provided information regarding the role of proteins involved in sperm physiology and functions in its various structural parts (Ciereszko et al., 2000). Specific key roles of proteins on a variety of processes have been linked to reproductive performance and gamete quality. Most of the studies concentrated on fish with commercial interest aiming at improvement in broodstock management, breeding strategies and sperm cryopreservation. In addition, proteomic analysis revealed to be a good indicator of cryopreservation success by assessing specific cryo-damage. Protein profiling based on two dimensional PAGE analysis can be used to separate very closely related proteins and to get a clear picture of various proteins in cells including spermatozoa (Pandey and Mann, 2000). This helps to understand the functional role of various proteins in seminal plasma and sperm (Dietrich et al., 2014). Even though artificial reproduction and cryopreservation of gametes are practiced in fish 
reproduction, the proteomics analysis of milt may further improve the techniques for assuring germ cell quality. Moreover, if molecular characteristics and the functional composition of gametes and seminal plasma are known, genetical and nutritional interventions can be incorporated for enhancing the reproductive potential of brooders.

Carps such as Labeo rohita (LR, Indian major carp), Labeo fimbriatus (LF, Indian minor carp), Cyprinus carpio (CC, Exotic carp) and Puntius carnaticus (PC, Kaveri carp, barb) are representatives of Cyprinidae family, with the first two carp species widely cultured in India and common carp cultured throughout the world, while $P$. caranaticus is widely present in the peninsular region of India. The breeding season of LR is in monsoon while that of LF and PC is post-monsoon but CC can be bred throughout the year if optimum conditions are provided. Interspecific variation in quantitative sperm morphology and protein profiling of sperm and seminal plasma has provided an opportunity for developing markers for male brood traits selection and for making strategies for ex situ conservation of the germplasm. Additionally, a comparative study between bull and fish seminal protein profiles has contributed basic information on protein changes in sperm environment related to internal and external fertilisations. Hence, the present study aimed to generate baseline information on the structure and morphometry of sperms as well as proteins abundance in the milt and sperm during breeding season, in four cyprinid species.

\section{Materials and methods}

\section{Sample collection}

Milt was collected from 3 individuals of each species of 1 year old L. rohita (190-200 g), L. fimbriatus (180-200 g), C. carpio (200-230 g) and P. carnaticus (140-150 g) from earthen ponds of ICAR-Central Institute of Freshwater Aquaculture (ICAR-CIFA), Regional Centre, Hessarghatta, Bangalore, India. The fish were injected with Ovatide (sGnRH analogues; HemaPharma, India) $0.02 \mathrm{ml} \mathrm{kg}^{-1}$ to induce breeding and the milt was collected by gentle stripping of abdomen after $6 \mathrm{~h}$ of injection. Utmost care was taken to avoid stress to the fish. For protein studies, milt samples were centrifuged at $11000 \mathrm{~g}$ for $15 \mathrm{~min}$ to separate seminal plasma from sperm cells. The sperm pellet and seminal plasma samples were snap frozen in liquid nitrogen and stored at $-80^{\circ} \mathrm{C}$ until protein analysis. For morphometric studies $50 \mu \mathrm{l}$ of samples were suspended in $1 \mathrm{ml}$ of buffer comprising $0.484 \%$ Tris calcium chloride (TC) (39.9 mMTris, $2.6 \mathrm{mMCaCl}_{2}$ ) and $1.5 \mathrm{mMNaN}_{3}$. Fishes were kept in separate tank for definite period and back to experimental ponds.

\section{Morphometry analysis}

The milt was diluted (1:200) in TC buffer and fixed by adding $2 \mu \mathrm{l}$ of neutral buffered formalin $(10 \%)$. Diluted semen samples of $10 \mu \mathrm{l}$ were mixed with $10 \mu \mathrm{l}$ of $3 \%$ rose bengal stain and an aliquot of $8 \mu$ l was smeared on glass slides. Smears were prepared in triplicate for all the 4 species. The slides were allowed to dry for 15-20 min and washed for one minute, dried and observed under phase contrast microscope (Nikon ECLIPSE 80 i). High resolution images of various fields were captured at $400 \mathrm{X}$. In each smear, 100 sperm cells were chosen for morphometric analysis. Morphometric parameters of spermatozoa viz., head length, head breadth, total length, head area, head radius, head diameter, mid piece length and flagellar length/tail length, were calculated using the software NIS elements BR3.1 (Nikon ECLIPSE 80 i). The flagellar length was measured from the mid piece (dark elongated spot like structure separating the head and tail portion) end to the tip of the flagella (Fig. 1).

\section{Extraction of protein}

The sperm pellets were thawed on ice and the sperm cells were centrifuged at $8000 \mathrm{~g}$ for $5 \mathrm{~min}$ at $4^{\circ} \mathrm{C}$ and the supernatant was discarded. This washing process was repeated two times and the pellet was re-suspended in $1 \mathrm{ml}$ TC buffer containing $10 \mu \mathrm{l} 0.1 \mathrm{M}$ phenyl methyl sulphonyl fluorides (PMSF). This step was followed by incubation at $0.1 \%$ Triton X-100 (Polyethyleneglycol 4-octyl phenyl ether) for $1 \mathrm{~h}$ at $4^{\circ} \mathrm{C}$ with intermittent vortexing at $10 \mathrm{~min}$ interval. After an hour, the samples were centrifuged at $13000 \mathrm{~g}$ for $30 \mathrm{~min}$ at $4^{\circ} \mathrm{C}$ and the supernatant containing sperm protein was collected in a fresh micro-centrifuge tube. The seminal plasma and sperm proteins were estimated by Bradford method using bovine serum albumin as a standard (Bradford, 1976).

\section{Protein profiling}

Protein profiling of fish samples were done using sodium dodecyl sulphate-polyacrylamide gel electrophoresis (SDS-PAGE) in order to identify species-specific protein variation. Based on the SDS-PAGE

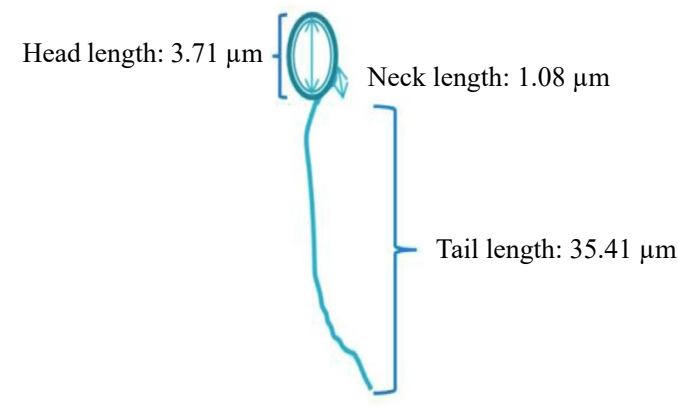

Fig. 1. Morphometry of carp sperm showing head length, tail length and neck 
protein profile variation among species, distantly related 2 fish samples were subjected to the two dimensional gel electrophoresis (2DE) technique. The results were compared with that of bull sperm protein.

\section{One-dimensional electrophoresis (SDS-PAGE)}

Sperm proteins and seminal plasma protein profiles were analysed by SDS-PAGE using 4\% stacking gel and $12 \%$ resolving gel (mini-PROTEAN tetra cells, Bio-Rad, Hercules, CA, USA). Sperm proteins (12 $\mu \mathrm{g}$ per lane) and seminal plasma protein $(20 \mu \mathrm{g}$ per lane $)$ were mixed with sample buffer $(0.5 \mathrm{M}$ trisHCl, Glycerol, $10 \% \mathrm{SDS}$, $\beta$-mercaptethanol, $0.05 \% \mathrm{w} / \mathrm{v}$ bromophenol blue) in the ratio $1: 1$ and denatured at $95^{\circ} \mathrm{C}$ for $5 \mathrm{~min}$ before loading. After electrophoresis, the gels were stained using silver nitrate and images were scanned in gel documentation system (SYNGENE, UK). The quantitative measurement of molecular weight, raw volume, height and quantity of the proteins were recorded from the software (Gene Tools, version 4.01.02, Syngene, UK).

\section{Two-dimensional gel electrophoresis (2D-GE)}

Based on morphometric analysis and SDS-PAGE profiling, two different fish species were selected for 2DE analysis. The 2D-GE was performed as per the method of O'Farrell et al. (1977) and D'Amours et al. (2010) with slight modifications using Protean IEF Cell and 2D starter kit (Bio-Rad, USA). The samples $(50 \mu \mathrm{g})$ were mixed with rehydration buffer and ampholyte to obtain $125 \mu \mathrm{l}$ final volume and dispensed to the isoelectric focusing (IEF) well and immobilised $\mathrm{pH}$ gradient IPG strips $(7 \mathrm{~cm}$ length and a $\mathrm{pH}$ range of 3-10, Bio Rad) were placed on the sample for rehydration. Rehydration was performed at $50 \mathrm{~V}$ for $16 \mathrm{~h}$ at $200 \mathrm{C}$ and IEF was performed with linear/rapid focusing conditions $(250 \mathrm{~V}, 500 \mathrm{~V}, 1000 \mathrm{~V}$, $3000 \mathrm{~V}, 8000 \mathrm{~V}$ until $13000 \mathrm{Vh})$. After IEF, the strips were equilibrated for half an hour in equilibration buffer (6 M Urea, $57 \mathrm{mM}$ TrisHCl, 29.3\% glycerol, 2\% SDS) containing dithiothreitol (DTT - 2.5\%) for $30 \mathrm{~min}$, followed by iodoacetamide (IAA - 2\%) in equilibration buffer for $30 \mathrm{~min}$ and rinsed in electrode buffer for $5 \mathrm{~min}$ at room temperature (DTT, 2.5\% iodoacetamide and 2\% SDS; $\mathrm{pH}$ 8.8 ). Further, the strip was loaded in $12 \%$ polyacrylamide gel, sealed with agarose (1\%) with bromophenol blue and performed electrophoresis. Gels were stained using silver nitrate and scanned in gel documentation system (G BOX ichemi XR, SynGene) and analysed using Dymension software (SynGene, version 2, UK).

\section{Statistical analysis}

Morphometry data were subjected to one-way ANOVA followed by Duncan's Multiple Range Test (DMRT) using SPSS package version 16.0. The Pearson- correlation analysis was performed between $2 \mathrm{DE}$ gel protein profiles. The data were presented as mean \pm SEM and $p<0.05$ was set as level of significance.

\section{Results}

Morphometry

The average volume of milt in LR, LF, CC and PC were $3.5,3.5,5.5$ and $1.25 \mathrm{ml}$, respectively (Table 1). $\mathrm{CC}$ had slight higher weight and a higher milt volume than the smaller sized PC. The morphometric features of different species are presented in Table 2 and a general structure is given in Fig. 1. The total length $(\mu \mathrm{m})$ of the sperm significantly differed $(\mathrm{p}<0.05)$ among the four species and the highest total length was observed in PC. The head length $(\mu \mathrm{m})$ and breadth $(\mu \mathrm{m})$ were significantly lower in LR as compared to PC and CC. The maximum head area $\left(\mu \mathrm{m}^{2}\right)$ was observed in CC similar to PC, but differed significantly $(\mathrm{p}<0.05)$ from LF and LR. The mid piece length $(\mathrm{Neck})$ was significantly $(\mathrm{p}<0.05)$ lower in LR compared to all other groups. Head diameter $(\mu \mathrm{m})$ was significantly higher in CC. From this study, it was observed that among the four species studied, LR and PC showed a wide difference in total length of the sperm, head length, mid-piece length, area and breadth of the head as compared to other species. The LR is closely related to LF whereas PC is closely related to CC (Table 2).

\section{Protein analysis}

Seminal plasma protein concentrations $\left(\mathrm{mg} \mathrm{ml}^{-1}\right)$ in all the four species did not differ significantly $(p<0.05)$ (Table 3). The plasma protein profile on SDS-PAGE exhibited 17-23 bands with molecular mass ranges equivalent to $7-212 \mathrm{kDa}$ in $\mathrm{LR}, \mathrm{LF}, \mathrm{CC}$ and $\mathrm{PC}$ respectively (Fig. 2). The molecular weights of common bands expressed in all the four species were 67, 51, 36, $34,26,10$ and 7. PC had additional protein bands (kDa) of 22, 54, 56, 75, 82 and 29, while LR had 43, 73, 97, 112, 131 and $180 \mathrm{kDa}$. Four protein bands equivalent to 58,91 , 123 and $212 \mathrm{kDa}$ were present in CC, whereas, LF plasma proteins exhibited molecular masses of 39, 35, 61, 62, 101 and $118 \mathrm{kDa}$ bands additionally (Fig. 2, Table 4).

The common carp sperm membrane protein concentration $\left(\mathrm{mg} \mathrm{ml}^{-1}\right)$ was $5.01 \pm 0.89 \mathrm{mg} \mathrm{ml}^{-1}$ and differed significantly $(\mathrm{p}<0.05)$ from other species, which

Table 1. Weight of the experimental fishes and milt obtained per fish in each group

\begin{tabular}{lll}
\hline Species & Weight $(\mathrm{g})$ & Milt per fish $(\mathrm{ml})$ \\
\hline L.rohita & $190-200$ & 3.5 (Range, 3-4 ) \\
L. fimbriatus & $180-200$ & 3.5 (Range, 3-4) \\
C. carpio & $200-230$ & 5.5 (Range 5-6 ) \\
P. carnaticus & $140-150$ & 1.25 (Range 1-1.5)
\end{tabular}


Table 2. Morphometric measurements $(\mu \mathrm{m})$ of spermatozoa of four cyprinids studied

\begin{tabular}{llllllll}
\hline Species & HL & TL & N & Total & HB & HD & HA \\
\hline LF & $4.90^{\mathrm{ab}} \pm 0.14$ & $26.86^{\mathrm{b}} \pm 0.99$ & $1.27^{\mathrm{a}} \pm 0.04$ & $32.96^{\mathrm{d}} \pm 1.04$ & $4.82^{\mathrm{ab}} \pm 0.12$ & $4.97^{\mathrm{b}} \pm 0.17$ & $23.51^{\mathrm{b}} \pm 2.69$ \\
LR & $4.34^{\mathrm{b}} \pm 0.14$ & $31.12^{\mathrm{a}} \pm 0.75$ & $1.05^{\mathrm{b}} \pm 0.03$ & $36.43^{\mathrm{c}} \pm 0.86$ & $4.52^{\mathrm{b}} \pm 0.11$ & $4.70^{\mathrm{b}} \pm 0.12$ & $20.56^{\mathrm{b}} \pm 1.36$ \\
CC & $5.36^{\mathrm{a}} \pm 0.29$ & $33.61^{\mathrm{a}} \pm 1.57$ & $1.29^{\mathrm{a}} \pm 0.11$ & $39.36^{\mathrm{b}} \pm 0.82$ & $5.62^{\mathrm{a}} \pm 0.42$ & $5.82^{\mathrm{a}} \pm 0.43$ & $31.96^{\mathrm{a}} \pm 2.29$ \\
PC & $5.18^{\mathrm{a}} \pm 0.24$ & $35.71^{\mathrm{a}} \pm 0.71$ & $1.40^{\mathrm{a}} \pm 0.06$ & $42.30^{\mathrm{a}} \pm .069$ & $5.50^{\mathrm{a}} \pm 0.19$ & $5.37^{\mathrm{ab}} \pm 0.04$ & $30.54^{\mathrm{a}} \pm 1.44$ \\
\hline
\end{tabular}

Data expressed as Mean $\pm \mathrm{SE}(\mathrm{n}=100) ; \mathrm{p}<0.005$. LF - L. fimbriatus, LR - L. rohita, CC - C. carpio, $\mathrm{PC}-$ P. carnaticus.

HL-Head length, TL-Tail length, N-Neck, HB-Breadth of sperm head, HD-Diameter of head, HA- Head area

Table 3. Protein concentration in sperm membrane and seminal plasma of the four carp species

\begin{tabular}{lll}
\hline Species & Protein concentration $(\mathrm{mg})$-SM & Protein concentration $\left(\mathrm{mg} \mathrm{ml}^{-1}\right)$-SP \\
\hline LR & $2.08^{\mathrm{b}} \pm 0.24$ & $0.50 \pm 0.03$ \\
LF & $2.62^{\mathrm{b}} \pm 0.16$ & $0.71 \pm 0.17$ \\
CC & $5.01^{\mathrm{a}} \pm 0.89$ & $1.05 \pm 0.36$ \\
PC & $2.55^{\mathrm{b}} \pm 0.26$ & $1.06 \pm 0.22$ \\
\hline
\end{tabular}

LR - L. rohita, LF - L. fimbriatus, CC - C. carpio, PC - P. carnaticus, SM - Sperm membrane, SP - Seminal plasma.

Table 4. Various seminal plasma proteins observed in SDS-PAGE in the four carp species

\begin{tabular}{|c|c|c|c|c|c|}
\hline $\mathrm{S} / \mathrm{N}$ & Protein $(\mathrm{KDa})$ & LF & LR & $\mathrm{PC}$ & $\mathrm{CC}$ \\
\hline 1 & 6 & $\mathrm{y}$ & & & \\
\hline 2 & 7 & $\mathrm{y}$ & $\mathrm{y}$ & $\mathrm{y}$ & $\mathrm{y}$ \\
\hline 3 & 10 & $\mathrm{y}$ & $\mathrm{y}$ & $\mathrm{y}$ & $\mathrm{y}$ \\
\hline 4 & 11 & $\mathrm{y}$ & $\mathrm{y}$ & & $\mathrm{y}$ \\
\hline 5 & 14 & & $\mathrm{y}$ & $\mathrm{y}$ & \\
\hline 6 & 22 & & & $\mathrm{y}$ & \\
\hline 7 & 26 & $\mathrm{y}$ & $\mathrm{y}$ & $\mathrm{y}$ & $\mathrm{y}$ \\
\hline 8 & 29 & & & $\mathrm{y}$ & \\
\hline 9 & 34 & $\mathrm{y}$ & $\mathrm{y}$ & $\mathrm{y}$ & \\
\hline 10 & 36 & $\mathrm{y}$ & $\mathrm{y}$ & $\mathrm{y}$ & $\mathrm{y}$ \\
\hline 11 & 41 & & $\mathrm{y}$ & $\mathrm{y}$ & \\
\hline 12 & 47 & $\mathrm{y}$ & & $\mathrm{y}$ & $\mathrm{y}$ \\
\hline 13 & 51 & $\mathrm{y}$ & $\mathrm{y}$ & $\mathrm{y}$ & $\mathrm{y}$ \\
\hline 14 & 59 & $\mathrm{y}$ & $\mathrm{y}$ & & \\
\hline 15 & 39 & $\mathrm{y}$ & & & \\
\hline 16 & 35 & $\mathrm{y}$ & & & \\
\hline 17 & 43 & & $\mathrm{y}$ & & \\
\hline 18 & 67 & $\mathrm{y}$ & $\mathrm{y}$ & $\mathrm{y}$ & $\mathrm{y}$ \\
\hline 19 & 61 & $\mathrm{y}$ & & $\mathrm{y}$ & $\mathrm{y}$ \\
\hline 21 & 224 & $\mathrm{y}$ & & & \\
\hline 22 & 118 & $\mathrm{y}$ & & & \\
\hline 23 & 101 & $\mathrm{y}$ & & & \\
\hline 24 & 54 & & & $\mathrm{y}$ & \\
\hline 25 & 56 & & & $\mathrm{y}$ & \\
\hline 26 & 75 & & & $\mathrm{y}$ & \\
\hline 27 & 279 & & $\mathrm{y}$ & & \\
\hline 28 & 264 & & $\mathrm{y}$ & & \\
\hline 29 & 180 & & $\mathrm{y}$ & & \\
\hline 30 & 131 & & $\mathrm{y}$ & & \\
\hline 31 & 122 & & $\mathrm{y}$ & & \\
\hline 32 & 112 & & $\mathrm{y}$ & & \\
\hline 33 & 97 & & $\mathrm{y}$ & & \\
\hline 34 & 58 & & & & $\mathrm{y}$ \\
\hline 35 & 91 & & & & $\mathrm{y}$ \\
\hline 36 & 123 & & & & $\mathrm{y}$ \\
\hline 37 & 212 & & & & $\mathrm{y}$ \\
\hline 38 & 82 & & & $\mathrm{y}$ & \\
\hline
\end{tabular}

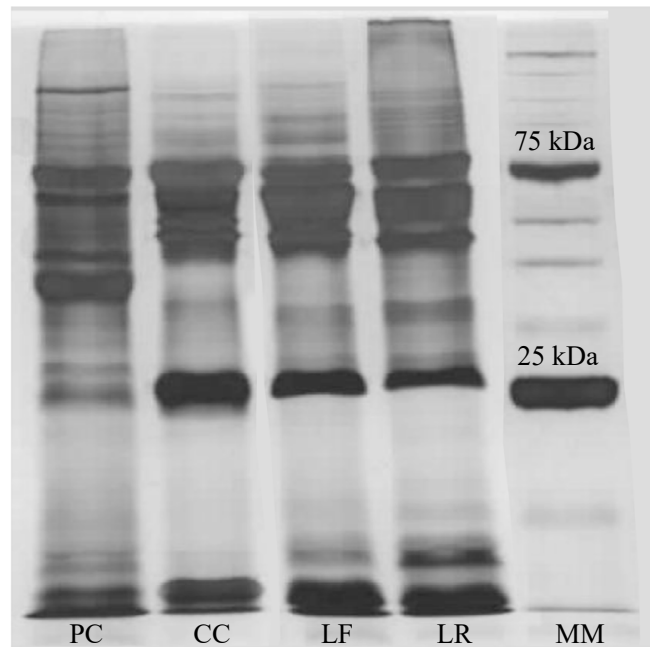

Fig. 2. Molecular weight $(\mathrm{kDa})$ of proteins in seminal plasma of four cyprinid species revealed by SDS-PAGE. Gels were stained with silver staining. PC - P. carnaticus, CC - common carp, LF - L. fimbriatus, LR - L. rohita, MM - molecular weight marker

were $2.08 \pm 0.24,2.62 \pm 0.16$ and $2.55 \pm 0.26$ in LR, LF and PC, respectively. However, there was no significant difference in seminal plasma protein concentration in all the four cyprinids. Analysis of sperm protein through SDS-PAGE showed that there was a difference in abundance of the proteins in these carps. The proteins equivalent to molecular weight $(\mathrm{kDa})$ of $64,61,58,56$, $45,41,36,32,27$ and 18 expressed ubiquitously in four species. However, $66 \mathrm{kDa}$ and $7 \mathrm{KDa}$ proteins were expressed in all species except LF. Similarly, $52 \mathrm{kDa}$ and $29 \mathrm{kDa}$ were not expressed in CC, while $20 \mathrm{kDa}, 21 \mathrm{kDa}$, $23 \mathrm{kDa}$ and $13 \mathrm{kDa}$ were not found in PC (Fig. 3, Table 5). 


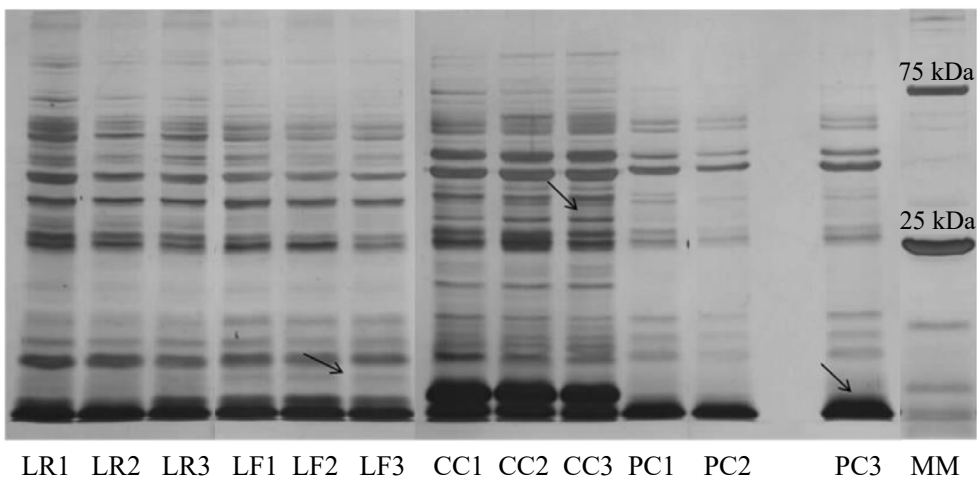

Fig. 3. Molecular weight $(\mathrm{kDa})$ of proteins in sperm membrane protein of four cyprinid species revealed by SDS-PAGE. Gels were stained with silver staining. LR-L. rohita, LF-L. fimbriatus, CC-common carp, PC- P. carnaticus, MM-molecular weight marker

Table 5. Various sperm membrane proteins observed in the four carp species

\begin{tabular}{|c|c|c|c|c|c|}
\hline $\mathrm{S} / \mathrm{N}$ & Protein (KDa) & LF & LR & $\mathrm{PC}$ & $\mathrm{CC}$ \\
\hline 1 & 237 & & $\mathrm{y}$ & & \\
\hline 2 & 129 & & & $\mathrm{y}$ & $\mathrm{y}$ \\
\hline 3 & 124 & & $\mathrm{y}$ & & \\
\hline 4 & 115 & $\mathrm{y}$ & $\mathrm{y}$ & $\mathrm{y}$ & \\
\hline 5 & 109 & $\mathrm{y}$ & & & \\
\hline 6 & 105 & & $\mathrm{y}$ & $\mathrm{y}$ & \\
\hline 7 & 95 & & $\mathrm{y}$ & $\mathrm{y}$ & \\
\hline 8 & 81 & $\mathrm{y}$ & & & \\
\hline 9 & 66 & & $\mathrm{y}$ & $\mathrm{y}$ & $\mathrm{y}$ \\
\hline 10 & 64 & $\mathrm{y}$ & $\mathrm{y}$ & $\mathrm{y}$ & $\mathrm{y}$ \\
\hline 11 & 61 & $\mathrm{y}$ & $\mathrm{y}$ & $\mathrm{y}$ & $\mathrm{y}$ \\
\hline 12 & 58 & $\mathrm{y}$ & $\mathrm{y}$ & & \\
\hline 13 & 58 & y & $\mathrm{y}$ & $\mathrm{y}$ & $\mathrm{y}$ \\
\hline 14 & 56 & Y & $\mathrm{y}$ & $\mathrm{y}$ & $\mathrm{y}$ \\
\hline 15 & 52 & y & $\mathrm{y}$ & $\mathrm{y}$ & \\
\hline 16 & 49 & & & $\mathrm{y}$ & \\
\hline 17 & 47 & $\mathrm{y}$ & $\mathrm{y}$ & & \\
\hline 18 & 45 & $\mathrm{y}$ & $\mathrm{y}$ & $\mathrm{y}$ & $\mathrm{y}$ \\
\hline 19 & 41 & $\mathrm{y}$ & $\mathrm{y}$ & $\mathrm{y}$ & $\mathrm{y}$ \\
\hline 20 & 37 & & & & $\mathrm{y}$ \\
\hline 21 & 36 & $\mathrm{y}$ & $\mathrm{y}$ & $\mathrm{y}$ & $\mathrm{y}$ \\
\hline 22 & 33 & $\mathrm{y}$ & & & \\
\hline 23 & 32 & $\mathrm{y}$ & $\mathrm{y}$ & $\mathrm{y}$ & $\mathrm{y}$ \\
\hline 24 & 29 & $\mathrm{y}$ & $\mathrm{y}$ & $\mathrm{y}$ & \\
\hline 25 & 27 & $\mathrm{y}$ & $\mathrm{y}$ & $\mathrm{y}$ & $\mathrm{y}$ \\
\hline 26 & 25 & & & & $\mathrm{y}$ \\
\hline 27 & 24 & & & & $\mathrm{y}$ \\
\hline 28 & 23 & $\mathrm{y}$ & $\mathrm{y}$ & & $\mathrm{y}$ \\
\hline 29 & 21 & $\mathrm{y}$ & $\mathrm{y}$ & & Y \\
\hline 30 & 20 & $\mathrm{y}$ & $\mathrm{y}$ & & $\mathrm{y}$ \\
\hline 31 & 18 & $\mathrm{y}$ & $\mathrm{y}$ & $\mathrm{y}$ & $\mathrm{y}$ \\
\hline 32 & 17 & & & & $\mathrm{y}$ \\
\hline 33 & 15 & & & $\mathrm{y}$ & \\
\hline 34 & 13 & $\mathrm{y}$ & $\mathrm{y}$ & & $\mathrm{y}$ \\
\hline 35 & 9 & $\mathrm{y}$ & $\mathrm{y}$ & & \\
\hline 36 & 7 & & $\mathrm{y}$ & $\mathrm{y}$ & $\mathrm{y}$ \\
\hline 37 & 4 & $\mathrm{y}$ & & $\mathrm{y}$ & \\
\hline
\end{tabular}

LR - L. rohita, LF - L. fimbriatus, CC - C. carpio, PC - P. carnaticus, $\mathrm{y}-\mathrm{yes}$; shows the presence of proteins
The percentage abundance of individual proteins were observed as 25 and $23 \%$ for molecular mass of 32 and $41 \mathrm{kDa}$, respectively, in LF, whereas the same for 45 $\mathrm{kDa}$ was $22 \%$ in LR, $24 \%$ for $45 \mathrm{kDa}$ in $\mathrm{PC}$ and 56 and $64 \mathrm{kDa}$ accounted for 15 and $17 \%$, respectively, in CC (Fig. 5).

\section{Proteins in bull and fish seminal plasma}

Bull seminal plasma showed 18 protein bands with molecular masses ranging from 8-68 kDa, while in fish it was 23 bands ranging from 7-212 kDa (Fig. 4). The maximum abundance of $46 \mathrm{kDa}$ protein was observed in bull, whereas in fish such abundance was recorded for protein band equivalent to $26 \mathrm{kDa}$. The maximum number of sperm protein was 18 and 27 in bull and fish samples respectively (Fig. 4).

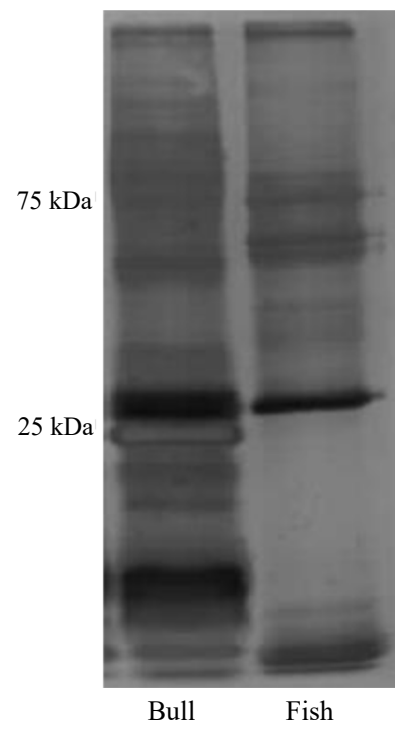

(a)

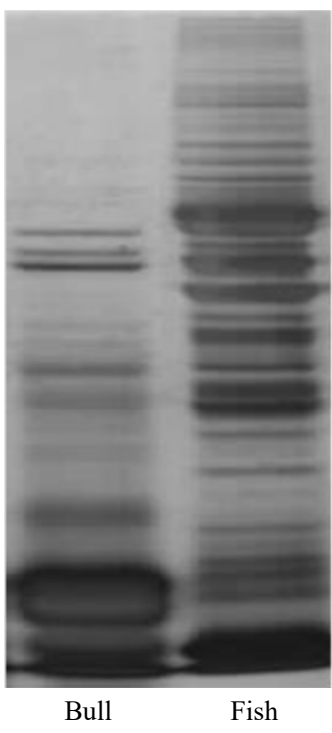

(b)
Fig. 4. Molecular weight (kDa) of proteins in (a) Seminal plasma and (b) Sperm membrane of bull and fish revealed by SDS-PAGE. Gels were stained by silver staining 


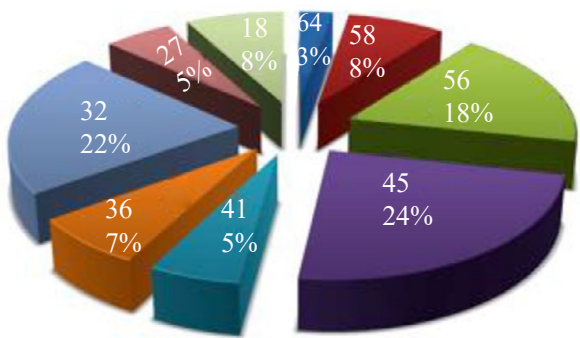

(a)

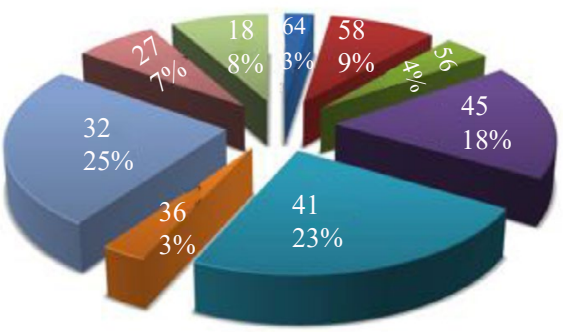

(c)

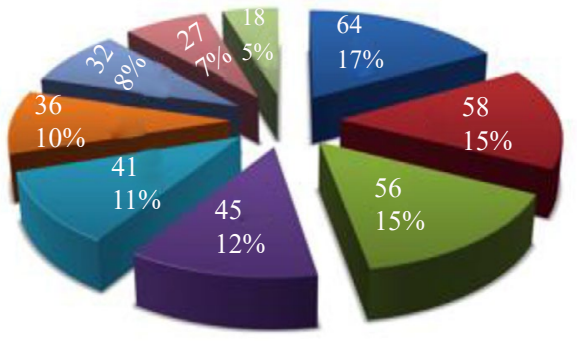

(b)

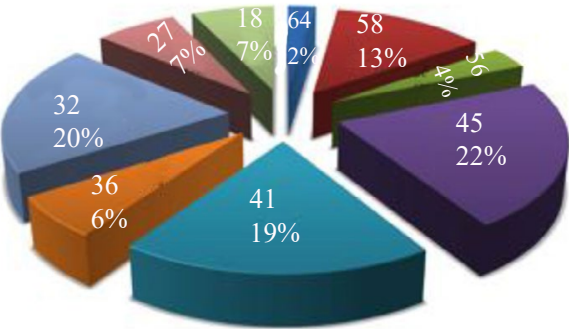

(d)

Fig. 5. Graphs showing the quantity of expressed sperm protein in (a) P. carnaticus; (b) C. carpio; (c) L. fimbriatus and (d) L. rohita. Proteins were quantified by densitometric analysis and abundance was compared

Two-dimensional gel electrophoresis (2D-GE)

As morphometric and SDS-PAGE analysis showed marked quantitative and qualitative variation among the species, two-dimensional analyses were performed for PC and LR. On 2D-GE study, we observed 237 common spots in two species, such as, spot no.193 (Fig. 6). Even though 196 spots were expressed almost equally in both species, 71 of them were up-regulated in PC compared to LR (Fig. 6). The correlation co-efficient and co-efficient of determination values were calculated as 0.84 and $73 \%$ respectively (Fig. 7). Some lower molecular weight proteins with varied $\mathrm{pI}$ such as, $10.57 \mathrm{kDa}, \mathrm{pI} 9.91$ and $8.60 \mathrm{kDa}$, pI 9.30 were present only in LR, while PC showed similar smaller proteins of molecular masses of $23.62 \mathrm{kDa}, \mathrm{pI} 4.64$ and $22.7 \mathrm{kDa}, \mathrm{pI} 6.38$.

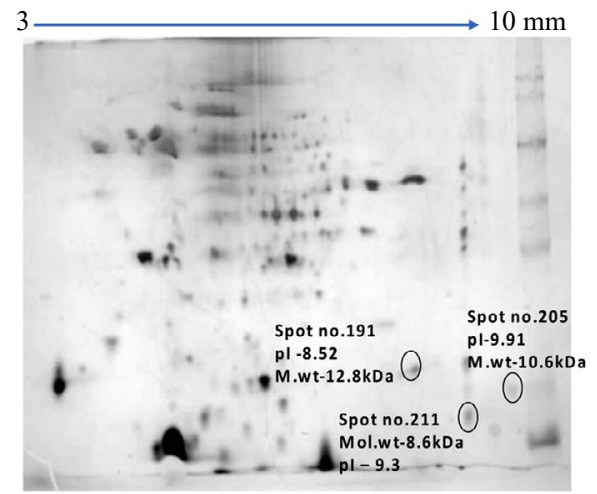

(a)

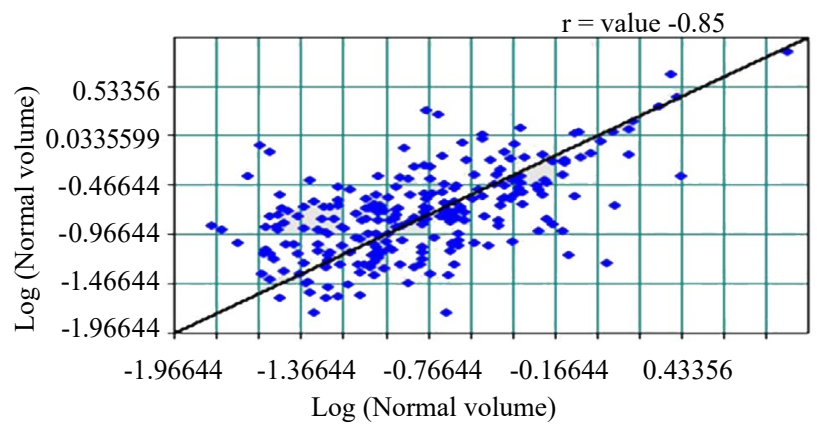

Fig. 7. Correlation chart of spots observed in 2D-GE analysis of L. rohita (Left) and P. carnaticus (right) sperm membrane protein

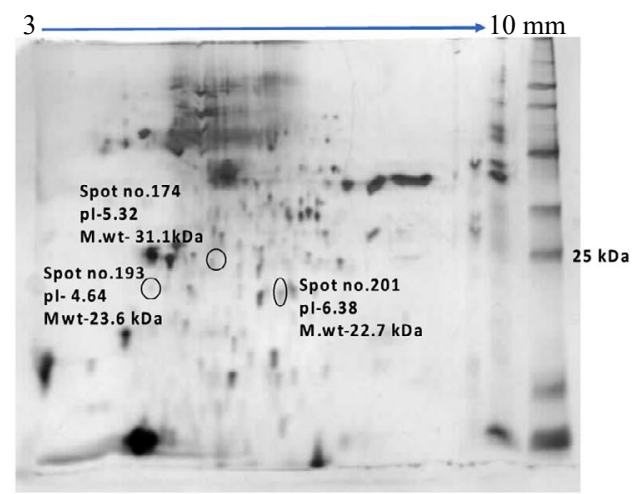

(b)

Fig. 6. 2D-GE analysis of (a) L. rohita and (b) P. carnaticus sperm membrane protein. Marked spots correspond to examples of proteins identified from 2D-GE which are differentially expressed in both the species 


\section{Discussion}

The studies related to intervention in reproduction require detailed understanding of the morphology of gametes. Studies on morphology of fish sperm especially of freshwater fish are scanty. Unlike terrestrial animals, fish show variety of reproductive patterns and most of them have external fertilisation (Tabosky, 1998). So there is ample differences in the structure and morphometry of sperm in fish when compared to cattle and human sperm. This might be the reason for higher expression of higher molecular weight proteins in both seminal plasma and sperm membrane proteins of fish compared to bull seminal samples in our study. In the present study we observed that the semen yield from different carp species were different. Total volume of milt from $C$. carpio after induction with Ovatide was greater than $6 \mathrm{ml}$ while that of L. rohita and L. fimbriatus was $3.5 \mathrm{ml}$. Khan et al. (1992) reported similar semen yield (3.63 ml kg-1 body weight) from L. rohita injected with pituitary gland extract. Similarly, milt yield from $P$. carnaticus without hormonal induction was $1.6 \mathrm{ml}$.

Most studies on sperm cytoskeleton are focused on the flagellar axoneme. Morphometric analysis of fish sperm revealed that unlike terrestrial animals, fishes have an ovoid head and flagella connected by a mid-piece. This cell lacks acrosome and possesses a flagellum attached to one side of the head region through the neck giving a "9" shaped structure to the sperm. These characteristics were similar to those reported in carps by Mattei (1974) and Stanley (1971). In most fish species, the flagellum axoneme bears the typical arrangement of nine pairs of peripheral microtubules and one pair of central microtubules, although some species such as eel (Anguilla anguilla) do not possess the central microtubules (Gibbons et al., 1983). This structure helps the spermatozoa travel through a narrow micropyle to reach the egg plasma membrane (Morisawa, 1985).

The plasma membrane of the spermatozoa head tightly overlays the nucleus and only a thin cytoplasmic layer remain between the plasma membrane and the nucleus. The shape of the sperm head varies with shape of the nucleus. Most nuclei show an invagination in which the axoneme will be anchored. As a consequence, nucleus shape will determine the strength of flagellar attachment to the head (Bobe and Labbe, 2010). It is reported that relatively small sperm head is observed in fishes (Johnson et al., 1983). The present study showed that sperm head length varies between 4.3 and $5.36 \mu \mathrm{m}$ with breadth ranging from 4.52 to $5.62 \mu \mathrm{m}$ in all the four species unlike the Atlantic eel, sturgeon and paddle fish sperm, which have elongated sperm head (Shaliutina, 2012). Different sperm shapes were observed in fishes, for example, laterally flattened (Perca fluviatilis), banana shape (Atlantic eel) and elongated (Mimagoniates barberi) and spherical in Mediterranean rainbow wrasse (Lahnsteiner and Patzner, 1997; Islam and Akhter, 2011). The flagellar length in fish varies from $2.6 \mu \mathrm{m}$ in coho salmon to $94 \mu \mathrm{m}$ in Channel catfish (Jaspers et al., 1976; Islam and Akhter, 2011). Our study showed flagellar length of four cyprinids between 26.86 and $35.71 \mu \mathrm{m}$ (Table 1), which was relatively within the range of 36 to $60 \mu \mathrm{m}$ reported in same family (Baccetti, 1984; Islam and Akhter, 2011). The coiling in flagellar tip occurs on dilution of carp spermatozoa in freshwater (Dreanno et al., 1999a). The reduction in flagellar length affects the motility of the sperm and it is determined by the ATP exhaustion of the mid piece mitochondria (Cosson, 2008).

Comparison between bull and fish seminal plasma and sperm membrane protein

Seminal plasma proteins of animals can be originated from blood as well as seminal plasma specific proteins. Comparison between fish and bull seminal plasma proteins revealed that the higher molecular weight proteins were more abundant in fishes compared to bull seminal plasma, which was dominated with lower molecular weight proteins. Similarly, abundance of high molecular weight proteins was significantly higher in fish sperm membrane. This revealed the importance of higher molecular weight proteins (above $60 \mathrm{kDa}$ ) for external fertilisation.

Seminal plasma and sperm membrane protein profiles among fishes

Proteins in seminal plasma are involved in the protection of spermatozoa and maintaining spermatozoa in the quiescent state, providing adequate levels of sperm nutrients for various physiological processes and protecting sperm against damage caused by proteolytic or oxidative attacks (Ciereszko et al., 2000). Study on seminal plasma is very critical to optimise the protocol for artificial fertilisation, storage and handling of sperm (Alavi et al., 2008). Moreover, a very few studies reported the relationship between fertilisation and seminal plasma concentration (Aas et al., 1991). Some of those proteins were identified as being involved in cell metabolism, oxido-reductase activity and signal transduction, membrane trafficking, organisation and cell movement (Li et al., 2010). Among species, there were distinct variations with the prominence of some species-specific bands in SDS-PAGE. P. carnaticus exhibited distinctly different pattern in sperm membrane and seminal plasma protein profile than other three species.

The seminal plasma proteins analysis revealed omnipresence of 7 bands among species with highest abundance of $7 \mathrm{kDa}$ proteins except in common carp, in 
which $26 \mathrm{kDa}$ was highly expressed. In another study, the 12 proteins identified in rainbow trout $(16-135 \mathrm{kDa})$ and 65 and $54 \mathrm{kDa}$ were dominant among them (Lahnsteiner, 2007). In most of the cyprinid species, $16 \mathrm{kDa}$ band was present in seminal plasma and may be responsible for energy supply and protection of sperm as reported in rainbow trout (Lahnsteiner, 2007). Asadpour et al. (2013) elucidated only nine proteins with molecular weights ranging from 11.74 to $68.12 \mathrm{kDa}$ in rainbow trout. Such variation in molecular masses may be attributed to the major defense against reactive oxygen species (ROS), owing to the low content of cytoplasm in spermatozoa (Shiva et al., 2011). The present study reveals quantitative and qualitative variation in sperm membrane proteins; LR showed presence of 28 bands of proteins ranging from 7-243 $\mathrm{kDa}$, while 23 bands of proteins in a range of 4-247 kDa were present in LF. PC and CC exhibited 16 and 30 bands in the range of 4-67 $\mathrm{kDa}$ and 6-104 $\mathrm{kDa}$, respectively. The observed variation in number and abundance of sperm membrane proteins may be either species specific (Kowalski et al., 2006) or due to various environmental, nutritional, seasonal and sampling conditions and variation in broodstock strains (Yue et al., 2009). In addition, variation in mode of reproduction among the species may contribute to such changes in sperm plasma membrane proteins responsible for the initiation of flagellar beating upon sperm release in water (Tubbs and Thomas, 2008), gamete fusion (Yu et al., 2002) and fertilisation (Beck et al., 1992).

\section{Two-dimensional analysis (2D-GE) of LR and PC}

In the present study, both morphometric and SDSPAGE revealed a significant difference among various species and LR and PC were mostly unrelated among the four carps. So we conducted further study to differentiate closely related proteins based on two-dimensional comparison of sperm membrane protein as we could observe wide variation among species in the seminal plasma protein in our SDS PAGE study. Moreover, there are several studies on seminal plasma proteins, which reported that there is a variation in seminal plasma protein in various stages of reproduction within species (Li et al., 2009, Shaliutina, 2012). The seminal plasma proteins/ molecules are mainly involved in protection and mobility of sperm in fishes when it is inside the body (Cosson et al., 1997, 2000; Borges et al., 2005), but outside the body, osmolality of environment plays major role in activation and mobility of sperm. A first time comparative analysis of blood proteome and seminal proteome using 2D electrophoresis reported 137 proteins in seminal proteome in which most of them were newly identified (Deitrich et al., 2014). In the present study, we detected that 237 spots were common between the two species. Even though
196 spots were expressed equally in both species, 71 of them were up or down regulated in either of the species. For improving the gamete quality during storage, further identification of these proteins need to be carried out to gain insight into their biological functions like signal transduction, ion binding, embryonic developmental processes, transportation of micro and macro molecules.

In conclusion, morphological studies indicated that the sperm of carps are acrosome less, uniflagellate with an ovoid head and irregular shaped mid piece. However, the species belonging to same family showed significant sperm size variation. The sperm and seminal protein profiles of $P$. carnaticus differed from other three groups with the presence and absence of certain proteins. The 2D-GE analysis of sperm protein profile between P. carnaticus and L. rohita revealed presence of 237 protein spots. Therefore, this morphometric feature of the species gives a baseline data for further study. In addition, the study observed a higher expression of higher molecular weight proteins in both seminal plasma and sperm membrane proteins of fish compared to bull seminal samples. Seminal plasma proteins and sperm proteins have to be further studied to understand the plasma specific protein and those proteins which can be specifically helping the reproductive viability of sperm.

\section{Acknowledgements}

We sincerely acknowledge the Directors of ICAR-NIANP, Bangalore, ICAR-CIFE, Mumbai and ICAR-CIFA, Bhubaneswar for their support in conducting this research work.

\section{References}

Aas, G. H., Refsteie, T. and Gjerde, B. 1991. Evaluation of milt quality of Atlantic salmon. Aquaculture, 95: 125-132.

Alavi, S. M. H. and Cosson, J. 2006. Sperm motility in fishes (II) Effects of ions and osmolality: A review. Cell. Biol. Int., 30: 1-4. doi: 10.1016/j.cellbi.2005.06.004.

Alavi, S. M. H., Cosson, J., Coward, K. and Rafiee, G. 2008 Fish spermatology. Alpha Science Ltd., Oxford, UK, 484 pp.

Asadpour, R., Tayefi-Nasrabadi, H. and Sheikhzadeh, N. 2013. Sodium Dodecyl Sulfate (SDS)-Polyacrylamide Gel Electrophoresis of rainbow trout (Oncorhynchus mykiss) seminal plasma proteins and their correlation with semen characteristics. Acta. Sci. Vet., 41(1): 1-6.

Ayyappan, S., Usha, M., Gopalakrishnan, A., Meenakumari, B., Jena, J. K. and Pandey, A.K. 2011. Handbook of fisheries and aquaculture, $2^{\text {nd }}$ edn. Directorate of Knowledge Management in Agriculture, Indian Council of Agricultural Research, New Delhi, India, 389 pp.

Baccetti, B., Burrini, A. G., Callaini, G., Gilbertini, G., Mazzini, M. and Zerunian, S. 1984. Fish germinal cells I. 
Comparative spermatology of seven cyprinid species. Gam. Res., 10: 373-396.

Beck, J. C., Fulcher, K. D., Beck, C. F. and Cloud, J. G. 1992. Sperm surface antigen required for fertility: Identification on spermatozoa of rainbow trout by use of monoclonal antibodies. Trans. Am. Fish. Soc., 121: 333-339.

Bobe and Labbe, 2010. Egg and sperm quality in fish. Gen. Comp. Endocrinol., 165(3): 538-548. doi: 10.1016/j. ygcen.2009.02.011.

Bonilla, E. and Xu, E. Y. 2008. Identification and characterisation of novel mammalian spermatogenic genes conserved from fly to human. Mol. Hum. Repro. Physiol., 14: 137-142. doi: 10.1093/molehr/gan002.

Borges, A., Siqueira, D. R., Jurinitz, F., Zanini, R., Amaral, F., do Grillo, M. L., Oberst, E. R. and Wassermann, G. 2005. Biochemical composition of seminal plasma and annual variations in semen characteristics of Jundiarhamdia quelen (Quoy and Gaimard, Pimelodidae). Fish Physiol. Biochem., 31: 45-53. DOI:10.1007/s10695-005-4742-8.

Bradford, M. M. 1976. Rapid and sensitive method for the quantitation of microgram quantities of protein utilising the principle of protein-dye binding, Anal. Biochem., 72: 248-254. https://doi.org/10.1016/0003-2697(76)90527-3.

Ciereszko, A., Glogowski, J. and Dabrowski, K. 2000. Biochemical characteristics of seminal plasma and spermatozoa of freshwater fishes. In: Tiersch, T. R. and Mazik, P. M. (Eds.), Cryopreservation in aquatic species. World Aquaculture Society, Louisiana, USA, p. 20-48.

Cosson, J., Billard, R., Cibert, C., Dreanno, C., Linhart, O. and Suquet, M. 1997. Movements of fish sperm flagella studied by high speed videomicroscopy coupled to computer assisted image analysis. Pol. Arch. Hydrobiol., 44(1-2): 103-113.

Cosson, J., Linhart, O., Mims, S. D., Shelton, W. L. and Rodina, M. 2000. Analysis of motility parameters from paddlefish and shovelnose sturgeon spermatozoa. J. Fish. Biol., DOI: 10.1111/j.1095-8649.2000.tb02148.x.

Cosson, J. J. 2008. The motility apparatus of fish spermatozoa. In: Alavi, S. M. H., Cosson, J., Coward, K. and Rafiee, G. (Eds.), Fish spermatology. Alpha Science Ltd., Oxford, UK, p. 281-316.

D'Amours, O., Frenette, G., Fortier, M., Leclerc, P. and Sullivan, R.2010. Proteomic comparison of detergent-extracted sperm proteins from bulls with different fertility indexes. Reproduction, 139(3): 545-556. doi: 10. 1530/REP-09-0375.

Dietrich, M. A., Arnold, G. J., Frohlich, T. and Ciereszko, A. 2014. In-depth proteomic analysis of carp (Cyprinus carpio L) spermatozoa. Comp. Biochem. Physiol. Part D Gen. Proteo., 12: 10-50.

Dreanno, C., Cosson, J., Suquet, M., Cibert, C., Fauvel, C., Dorange, G. and Billard, R. 1999. Effects of osmolality, morphology perturbations and intracellular nucleotide content during the movement of seabass (Dicentrarchus labrax) spermatozoa. J. Reprod. Fertil., 116: 113-125.

Gibbons, G. W., Hawking, S. W. and Siklos, S. T. C. 1983. The very early universe, Proceedings of the Nuffield Workshop, 21 June-09 July, 1982, Cambridge, Cambridge University Press, Cambridge, UK.

Islam, M. S. and Akhter, T. 2011. Tale of fish sperm and factors affecting sperm motility: A review. Adv. Life. Sci., 1(1): 11-19. doi: 10.5923/j.als.20110101.03.

Jacobson, L. D., Bograd, S. J., Parris, R. H., Mendelssohn, R. and Schwing, F. B. 2005. An ecosystem-based hypothesis for climatic effects on surplus production in California sardine (Sardinops sagax) and environmentally dependent surplus production models. Can. J. Fish. Aquat. Sci., 62: 1782-1796.

Jaspers, E. J., Avault, J. W. and Roussel, J. D. 1976. Spermatozoal morphology and ultrastructure of channel catfish, Ictalarus punctatus. Trans. Am. Fish. Soc., 150: 475-480. https:// doi.org/10.1577/1548-8659(1976)105<475:SMAUOC $>2$. $0 . \mathrm{CO} ; 2$.

Johnson, C. H., Clapper, D. L. and Winkler, M. M. 1983. A volatile inhibitor immobilizes sea urchin sperm in semen by de-pressing intracellularpH. Develop. Biol., 98:493-501. doi: 10.1016/0012-1606(83)90378-0.

Khan, H. A., Gupta, S. D. and Tantia, M. S. 1992. A new method to induce spermiation, ovulation by hypophysation in the Indian major carp Labeo rohita. J. Aquac. Trop., 7: 143-150.

Kowalski, R. K., Hliwa, P. and Andronowska, A. 2006. Semen biology and stimulation of milt production in the European smelt (Osmerus eperlanus L.). Aquaculture, 261: 760-770.

Lahnsteiner, F. and Patzner, R. A. 1997. Fine structure of spermatozoa of four littoral teleosts Symphodus ocellatus, Coris julius, Thalassoma pavo and Chromis chromis. J. Submicrosc. Cytol. Pathol., 29: 477-485.

Lahnsteiner, F. 2007. Characterisation of seminal plasma proteins stabilizing the sperm viability in rainbow trout (Oncorhynchus mykiss). Anim. Reprod. Sci., 97(1-2): 151-164. doi: 10.1016/j.anireprosci.2006.01.003.

Li, P. Hulak, M., Koubek, P., Sulc, M., Dzyuba, B. and Boryshpolets, S. 2010. Ice-age endurance: The effects of cryopreservation on proteins of sperm of common carp, Cyprinus carpio L. Theriogenology, 74: 413-423. doi: 10.1016/j.theriogenology.2010.02.024.

Maricchiolo, G., Genovese, L., Laura, R., Micale, V. and Muglia, U. 2002. The ultrastructure of amberjack (Seriola dumerilii) sperm. Eur. J. Morphol., 40(5): 289-292. doi: 10.1076/ejom.40.5.289.28902.

Maricchiolo, G., Genovese, L., Laura, R., Micale, V. and Muglia, U. 2004. Fine structure of spermatozoa in the common pandora (Pagellus erythrinus Linnaeus, 1758) (Perciformes, Sparidae). Histol. Histopathol., 19: 1237-1240. 
Mattei, C. and Mattei, X. 1974. Spermiogenesis and spermatozoa of the Eiopomorpha (teleost fish). In: Afzelius, B. A. (Ed.), The functional anatomy of the spermatozoon. Pergamon Press, Oxford, UK, p. 211-221.

Mattei, X. 1991. Spermatozoon ultrastructure and its systematic implication in fish. Can. J. Zool., 69: 3038-3055.

Migaud, H. G., Bell, E., Cabrita, B., McAndrew, A., Davie, J. B., Herraez M. P. and Carrillo, M. 2013. Gamete quality and broodstock management in temperate fish. Rev. Aquac., 5: 194-202. https://doi.org/10.1111/raq.12025.

Morisawa, M. 1985. Initiation mechanism of sperm motility at spawning in teleosts. Zool. Sci., 2: 605-615.

O'Farrel, P. Z., Goodman, H. M. and O'Farrel, P. H. 1977. High resolution two dimensional electrophoresis of basic as well as acidic proteins. Cell, 12: 1133-1141. doi: 10.1016/00928674(77)90176-3.

Pandey, A. and Mann, M. 2000. Proteomics to study genes and genomes. Nature, 405: 837-846. doi: 10.1038/35015709.

Pandey, A. K. 2013. Dietary and hormonal manipulations for gonadal and seed production of Indian major carps and catfishes. J. Exp. Zool. India, 16: 19-17.

Selvaraju, S., Ghosh, J. and Ravindra, J. P. 2009. Prognostic value of various spermatological attributes as predictors of zona binding and zona penetration of buffalo (Bubalus bubalis) semen. Repro. Dom. Anim., 44: 6-11. doi: 10.1111/j.14390531.2007.00979.x.

Shaliutina, A., Hulak, M., Dzuyba, B. and Linhart, O. 2012. Spermatozoa motility and variation in the seminal plasma proteome of Eurasian perch (Perca fluviatilis) during the reproductive season. Mol. Reprod. Dev., 79: 879-887. doi: $10.1002 / \mathrm{mrd} .22126$.

Shiva, M., Gautam, A. K., Verma, Y., Shivgotra, V., Doshi, H. and Kumar, S. 2011. Association between sperm quality, oxidative stress and seminal antioxidant activity. Clin. Biochem., 44: 319-324. doi: 10.1016/j.clinbiochem. 2010.11.009.

Stanley, H. P. 1971. Fine structure of spermiogenesis in the Elasmobranch fish Squalus suckleyi II. Late stages of differentiation and structure of the mature spermatozoan. J. Ultrastr. Res., 36: 103-118. https://doi.org/10.1016/ S0022-5320(71)80091-6.

Tabosky, M. 1998. Sperm cornpetition in fish: "bourgeois" males and parasitic spawning. Trend. Ecol. Evol., 13: 222-227.

Tubbs, C. and Thomas, P. 2008. Functional characteristics of membrane progestin receptor alpha (mPR[alpha]) subtypes: A review with new data showing mPR[alpha] expression in sea trout sperm and its association with sperm motility. Steroids, 73: 935-941. doi: 10.1016/j.steroids.2007.12.022.

Yu, S., Kojima, N., Hakomori, S. I., Kudo, S., Inoue, S. and Inoue, Y. 2002. Binding of rainbow trout sperm to egg is mediated by strong carbohydrate-to carbohydrate interaction between KDN GM3 (deaminatedneuraminylganglioside) and Gg3-like epitope. Proc. Nat. Acad. Sci. USA, 99: 2854-2859. doi: 10.1073/pnas.052707599.

Yue, W., Shi, L., Bai, Z., Ren, Y. and Zhao, Y. 2009. Sodium dodecyl sulfate (SDS)-polyacrylamide gel electrophoresis of ram seminal plasma proteins and their correlation with semen characteristics. Reprod. Biol. Endocrinol., 116(3-4): 386-391. doi: 10.1016/j.anireprosci.2009.02.014. 